ORIGINAL ARTICLE

\title{
Protocol optimization for the detection of Trypanosoma cruzi DNA in açai (Euterpe oleraceae) pulp
}

Gabrielle Virgínia Ferreira CARDOSO ${ }^{1 *}{ }^{\circledR}$, Andrey Carlos do Sacramento de OLIVEIRA ${ }^{2}$, Andréia Silva da SILVA ${ }^{1}$, Marcos Clécio de Lemos SILVA ${ }^{3}$, Joelson Sousa LIMA ${ }^{1}$, Talita Bandeira ROOS ${ }^{1}$, Carina Martins de MORAES $^{1}$

1Universidade Federal do Pará, Instituto de Medicina Veterinária, Laboratório de Higiene e Qualidade de Alimentos, BR 316, Km 62, Saudade ll , Castanhal - PA, Brazil
${ }^{2}$ Universidade Maurício de Nassau, Av. Gentil Bitencourt, 98, Batista Campos, Belém - PA, Brazil

3 Universidade Norte do Paraná, Av. Máximino Porpino Silva, 2002, Centro, Castanhal - PA, Brazil

*Corresponding author: gabi.virginia.mv@gmail.com; (DD http://orcid.org/0000-0002-6407-2068

\section{ABSTRACT}

Chagas disease, caused by the protozoan Trypanosoma cruzi, has often been linked to oral transmission through açai consumption. Molecular methods that allow fast and accurate identification of the pathogen are important for the detection of the presence of the parasite in this food. This study aimed to optimize polymerase chain reaction (PCR)-based detection of T. cruzi DNA in açai pulp. Several dilutions of T. cruzi DTU TcI trypomastigote forms were cultured in liver infusion tryptose (LIT) medium. Trypanosoma cruzi DNA was extracted from the cells and subjected to PCR. Subsequently, culture dilutions were added to açai pulp to evaluate the detection threshold of the optimized PCR assay. We demonstrate that our assay can detect T. cruzi DNA in açai pulp at a concentration of $1.08 \times 10^{-10} \mathrm{ng} \mu \mathrm{L}^{-1}$. We conclude that our optimized protocol is effective and can be used as an important tool for the detection of T. cruzi contamination in açaí.

KEYWORDS: detection method; foodborne disease; food pathogen; molecular detection; Chagas disease

\section{Otimização de protocolo para detecção de DNA de Trypanosoma cruzi em polpa de açaí (Euterpe oleracea)}

\section{RESUMO}

A doença de Chagas, enfermidade causada pelo protozoário Trypanosoma cruzi, tem sido relacionada com frequência à transmissáo oral pelo consumo de açaí. Métodos moleculares que fornecem uma identificaçáo rápida e precisa do patógeno para a detecção da presença do parasita são de extrema importância para a detecção da presença do parasita neste alimento. Este estudo teve como objetivo otimizar a detecçáo de DNA de T. cruzi em polpa de açaí por meio da reaçáo em cadeia da polimerase (PCR). Foram preparadas várias diluiçōes das formas tripomastigotas de T. cruzi DTU TcI cultivadas em meio de cultivo Liver Infusion Tryptose. O DNA de T. cruzi foi extraído das células e submetido à PCR. Posteriormente, as diluições da cultura foram adicionadas às polpas de açaí para avaliar o limite de detecção do novo ensaio de PCR otimizado. Mostramos que nosso ensaio pode detectar DNA de T. cruzi em polpas de açaí na concentração de $1.08 \times 10^{-10} \mathrm{ng} \mu \mathrm{L}^{-1}$. Concluímos que a metodologia desenvolvida se mostra eficaz e pode ser uma ferramenta importante para a detecção de contaminação por $T$. cruzi em açaí.

PALAVRAS-CHAVE: métodos de detecção; doenças transmitidas por alimentos; patógenos alimentares; detecção molecular; doença de Chagas 


\section{INTRODUCTION}

Trypanosoma cruzi Chagas, 1909 is a unicellular eukaryote that belongs to the kingdom Protozoa, order Kinetoplastida, and family Trypanosomatidae (Adl et al. 2012). This protozoan was described by Carlos Chagas in 1909 as the etiological agent of Chagas disease (CD) (Chagas 1909) and is characterized by a complex biological cycle that includes an intermediate host (triatomine arthropods), a definitive host (human), and various classes of mammalian hosts that act as domestic, peridomiciliary, and wild reservoirs (WHO 2017).

Oral transmission of CD was experimentally demonstrated for the first time, when trypomastigotes of the parasite were orally administered to laboratory animals (Nathan-Larrier 1921). In 2008, the route taken by orally inoculated metacyclic trypomastigotes of $T$. cruzi was described, revealing that these forms were capable to avoid gastric digestion by protecting themselves in the mucin layer and crossing the gastric mucosa (Yoshida 2008). Recently it was demonstrated that genetic factors can influence oral infectivity and that the high mortality rates in cases of human oral transmission can be explained by factors such as size of the inoculum, parasite genetics and lack of previous exposure to T. cruzi (Lewis et al. 2018). However, factors such as poor hygiene conditions during fruit handling and transport also affect the oral transmission of the pathogen (Xavier et al. 2014). Therefore, studies on the importance of these factors in the oral transmission of T. cruzi are necessary.

In northern Brazil, oral transmission of T. cruzi is frequent, especially in the Amazon region, where outbreaks of CD are associated with the consumption of contaminated pulp of açai berries (Euterpe oleracea Martius) (Filigheddu et al. 2017; Shikanai-Yasuda et al. 2018; Brazil 2019). Contaminated Brazilian açai berries have the potential to spread CD worldwide, as they are exported to many countries. Therefore, the detection of contaminants of açai berries is important for both public health and compliance with sanitary rules for commercial export.

Food parasites are generally detected using microscopic examination, which is not a highly sensitive technique (Godoi et al. 2017). Therefore, PCR-based molecular methods have been used to detect pathogenic contamination in various foods (Alves et al. 2018; Ferreira et al. 2018; Oliveira et al. 2018).

Although the prevention of $\mathrm{CD}$ from oral transmission is of great relevance to public health, current methods of detection of T. cruzi in açai pulp are ineffective due to the dark color of the fruit, high levels of organic matter (vegetable fibers) and characteristic physical-chemical properties of the pulp (Costa et al. 2018). Currently, there is no official method for the direct detection of T. cruzi in food (Ferreira et al. 2016) and the polymerase chain reaction (PCR), which has already been used for the diagnosis of infectious diseases (Cássia-Pires et al., 2017; Silveira et al. 2018; Cardoso et al. 2020), can potentially be used for this purpose due to its advantage in the fast and accurate identification of the pathogen (Cardoso et al. 2020).

Several studies have tested the use of PCR-based techniques for the detection of T. cruzi DNA in food, including açai (Ferreira et al. 2016; Mattos et al. 2017; Godoi et al. 2017), but the efficacy of the technique still needs to be improved. The quality of the extracted DNA is of paramount importance, because an effective DNA extraction method that provides sufficient inhibitor-free DNA is crucial for high-sensitivity molecular techniques (Santos et al. 2009). Commercial DNA extraction kits offer the advantage of maintaining a quality standard for the extracted material. A wide variety of commercial DNA extraction kits are currently available, but only a few can be used for DNA purification from food products (Branquinho et al. 2012).

Thus, the aim of the present study was to present an optimized protocol of high efficiency and sensitivity for PCR detection of T. cruzi DNA extracted directly from açai pulp through the modification of a commercial kit for DNA extraction from tissue samples, including the evaluation of the detection limit of the technique.

\section{MATERIAL AND METHODS}

DNA was extracted from $3.5 \times 10^{4}{ }^{-1}$ T. cruzi discrete typing unit (DTU) TcIV isolate obtained from the protozoology collection of Fundação Instituto Oswaldo Cruz, Rio de Janeiro, Brazil. Genomic DNA was extracted using the Illustra $^{\mathrm{TM}}$ blood genomicPrep Mini Spin Kit (GE Healthcare, Buckinghamshire, UK), according to the manufacturer's recommendations.

The extracted DNA was quantified using a spectrophotometer (NanoDrop ${ }^{\mathrm{TM}}$ Lite Spectrophotometer, ThermoFisher, Waltham, Massachusetts, EUA). Absorbance was measured at $260 \mathrm{~nm}$ (A260), $280 \mathrm{~nm}$ (A280), and $230 \mathrm{~nm}$ (A230) to assess the concentration of nucleic acids, proteins, and organic contaminants, respectively. The extracted DNA was subsequently electrophoresed on a $1 \%$ agarose gel in Tris-Borate-EDTA (TBE) buffer. The gel was stained with $6 \times$ GelRed" $^{\prime \prime}(1 \mu \mathrm{L}$ dye $/ 5 \mu \mathrm{L}$ sample) and the results were analyzed using a gel documentation system (Gel Doc $\mathrm{Xr}^{\mathrm{Tm}}{ }^{\mathrm{m}}$, Bio-Rad $\left.{ }^{\oplus}, \mathrm{USA}\right)$.

For PCR, two primers previously described by Ochs et al. (1996), TCZ3 (5'-TGCTGCASTCGGCTGATCGTT TTCGA-3') and TCZ4 (5'-CARGSTTGTTTGGTGTCC AGTGGTTGTG-3'), were eluted in TE buffer ( $\mathrm{pH}$ 8.0) to a concentration of $10 \mathrm{pmol} \mu \mathrm{L}^{-1}$, to amplify the sequence of approximately $149 \mathrm{bp}$.

The PCR mix comprised 0.5 IU Taq DNA polymerase, $100 \mathrm{mM}$ Tris- $\mathrm{HCl}$ (pH 8.5), $500 \mathrm{mM} \mathrm{KCl,}, 50 \mathrm{mM} \mathrm{MgCl}$, 
$0.2 \mathrm{mM}$ of each dNTP, $5 \mathrm{pmol}$ of each primer, and $133.6 \mathrm{ng}$ $\mu \mathrm{L}^{-1}$ template DNA in a final volume of $25 \mu \mathrm{L}$.

The PCR reaction was performed in a thermocycler (Veriti 96 Well Thermal Cycler, Applied Biosystems ${ }^{\oplus}$, Foster City, California, USA). The cycling parameters were as follows: initial denaturation at $94^{\circ} \mathrm{C}$ for $5 \mathrm{~min}$; followed by 35 cycles of denaturation at $94^{\circ} \mathrm{C}$ for $30 \mathrm{~s}$, annealing at $55^{\circ} \mathrm{C} / 56$ ${ }^{\circ} \mathrm{C} / 57^{\circ} \mathrm{C}$ for $20 \mathrm{~s}$, and extension at $72{ }^{\circ} \mathrm{C}$ for $20 \mathrm{~s}$; and final extension at $72{ }^{\circ} \mathrm{C}$ for $7 \mathrm{~min}$. The amplified samples were stored at $4{ }^{\circ} \mathrm{C}$ for further analysis.

The PCR amplicons were subjected to electrophoresis on a $2 \%$ agarose gel in $0.5 \%$ TBE buffer. The gel was stained with GelRed $^{\oplus}$ non-mutagenic dye and the results were analyzed using an ultraviolet light transilluminator with an image capture system (Gel Doc XR+ Gel Documentation System, Hercules, California, USA).

To assess the detection limit of the methodology, after optimizing the extraction method and defining the parameters of the PCR assay, the T. cruzi DTU TcIV DNA was serially diluted from an initial concentration of $133.6 \mathrm{ng} \mathrm{LL}^{-1}$ until the maximum dilution where it was still possible to detect the parasite. PCR amplification of DNA samples was performed in quintuple to determine the reproducibility of the assay.

The detection limit for the parasite DNA extracted from the açai pulp was determined by experimental contamination with the same isolate used for PCR optimization (T. cruzi DTU TcIV trypomastigote). In this procedure, the parasite was cultured in liver infusion trypsin (LIT) medium in a greenhouse at $28{ }^{\circ} \mathrm{C}$. Subsequently, $3.0 \times 10^{4}$ parasite cells were diluted to $10^{-10} \mathrm{~mL}^{-1}$ cells, and $1 \mathrm{~mL}$ of the suspension of each dilution was added to $9 \mathrm{ml}$ of pre-bleached açai pulp (80 ${ }^{\circ} \mathrm{C}$ for $10 \mathrm{~s}$, followed by cooling to $7^{\circ} \mathrm{C}$ ). The contamination was performed with 10 dilutions in quintuple, totalling 50 samples.

The parasite's DNA was extracted from each of the 50 samples using the Illustra ${ }^{\text {тм }}$ Tissue and Cells genomicPrep
Mini Spin Kit (GE Healthcare, Buckinghamshire, UK), according to the manufacturer's recommendations and with modifications, aiming at determining the most appropriate protocol. The modifications consisted of diluting $200 \mu \mathrm{L}$ of the contaminated açai sample in $100 \mathrm{~mL}$ PBS (phosphatebuffered saline) buffer followed by centrifuging at 14,000 $\times \mathrm{g}$ for $2 \mathrm{~min}$. The pellet was suspended in $100 \mathrm{~mL}$ PBS. The cells were lysed, and DNA was purified in $50 \mu \mathrm{L}$ of the solution supplied by the manufacturer. The extracted DNA was kept at $37^{\circ} \mathrm{C}$ for $5 \mathrm{~min}$, then stored at $4{ }^{\circ} \mathrm{C}$.

The extracted DNA was quantified using a Nanodrop Lite $^{\circledast}$ spectrophotometer, using 260-nm, 280-nm and 230-nm filters. The DNA quality was assessed by electrophoresis on a $1 \%$ agarose gel in TBE buffer, and the gel was stained with the $6 \times$ GelRed $^{\text {TM }}$ dye $(1 \mu \mathrm{L}$ dye $/ 5 \mu \mathrm{L}$ sample). The extraction protocol that provided the most adequate DNA samples in terms of purity was considered for later analyses.

Subsequently, these DNA samples were subjected to PCR in triplicate, according to the PCR protocol previously described, to evaluate the possibility of amplifying the DNA extracted from the açai pulp. Following PCR, one of the amplicons obtained was sequenced by ACTGene Análises Moleculares Ltda. using an automated sequencer (ABI PRISM 3130 Genetic Analyzer XL, Applied Biosystems ), following the ABI PRISM Big Dye Terminator Cycle protocol. Consensus sequences obtained from the GenBank database were subjected to a BLASTn search (http://www.ncbi.nlm. nih.gov) for comparison. The significance of the alignments was defined based on the e-value analysis.

A phylogenetic tree was built with the aid of the Blast Tree View ${ }^{\oplus}$ program (https://www.ncbi.nlm.nih.gov/blast/ treeview/treeView.cgi), by the Fast Minimum Evolution method, that calculated an alignment between the pairs of the query and the sequences of the NCBI database for all parasites belonging to the genera Leishmania or other species of Trypanosoma registered in the database.

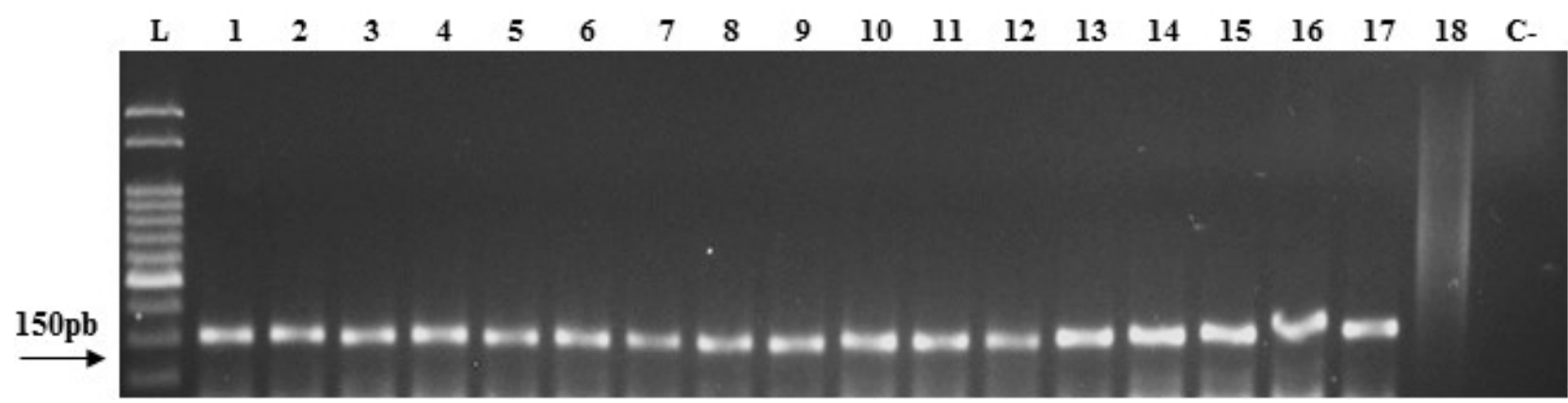

Figure 1. A 2\% agarose gel showing T. cruzi DNA fragments (approximately $149 \mathrm{bp}$ ). L: 50-bp marker; lane 1: dilution of DNA $10^{\circ}$ (equivalent to a concentration of

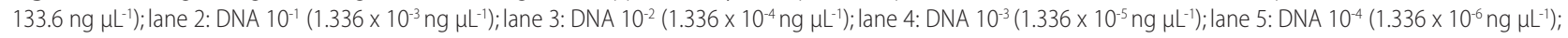

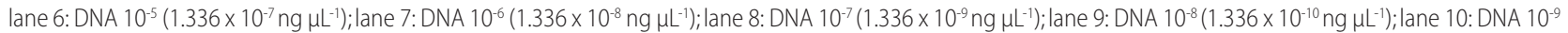

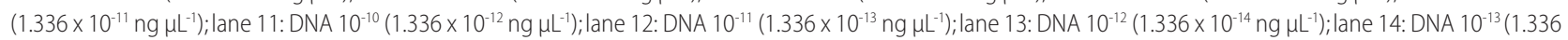
$\left.\times 10^{-15} \mathrm{ng} \mu \mathrm{L}^{-1}\right)$; lane 15: DNA $10^{-14}\left(1.336 \times 10^{-16} \mathrm{ng} \mu \mathrm{L}^{-1}\right)$; lane 16: DNA $10^{-15}\left(1.336 \times 10^{-17} \mathrm{ng} \mu \mathrm{L}^{-1}\right)$; lane 17: DNA $10^{-16}\left(1.336 \times 10^{-18} \mathrm{ng} \mu \mathrm{L}^{-1}\right)$ - detection threshold; lane 18 : DNA $10^{-17}\left(1.336 \times 10^{-19} \mathrm{ng} \mathrm{\mu L}^{-1}\right) ; \mathrm{C}-$ : negative control. 


\section{RESULTS}

The optimized PCR assay detected T. cruzi DNA with good accuracy and precision when $57^{\circ} \mathrm{C}$ for $30 \mathrm{~s}$ was used in the annealing step. The optimized PCR showed a detection threshold of $1.336 \times 10^{-18} \mathrm{ng} \mu \mathrm{L}^{-1}$ for T. cruzi DNA (Figure 1).

With regard to the experimental contamination of açai pulp, the average concentration of DNA extracted from all 50 analyzed samples was $10.8 \mathrm{ng} \mu \mathrm{L}^{-1}$. The extracted DNA samples usingthe modifications of the original protocol had a clear appearance, indicating that the pigments present in açai that could inhibit the reaction were eliminated. The mean absorbance (A260/280) and (A260/230) values were $1.9 \pm$ 1.0 and $2.0 \pm 1.4$ D.O., respectively. The detection limit of T. cruzi DNA in the dilutions of contaminated pulp was $3 \times$ $10^{-6}$ cells mL $\mathrm{mL}^{-1}$ of $T$. cruzi, which corresponded to $1.08 \times 10^{-10}$ ng $\mu^{-1}$ of DNA in the sample (Figure 2).

Analysis of the fragment sequenced in this study revealed significant identity with T. cruzi DNA. The sequenced fragment showed $100 \%$ identity and $97 \%$ coverage with the subject sequence DQ914506.1 (T. cruzi clone VL10_1_1 satellite sequence) accessed from GenBank ${ }^{\ominus}$. Moreover, no significant similarity was found between the T. cruzi DNA sequence and DNA sequences of parasites belonging to Leishmania or other species of Trypanosoma (Figure 3).

\section{DISCUSSION}

Ferreira et al. (2016) proposed a benchtop protocol for extracting T. cruzi DNA from foods using detergent CTAB (cetyltrimethylammonium bromide). However, they could only achieve PCR amplification of the parasite DNA with a minimum concentration of 2.5 cells $\mathrm{mL}^{-1}$ of açai. We achieved amplification of $T$. cruzi DNA from a much lower inoculum concentration $\left(3 \times 10^{-6}\right.$ cells $\left.\mathrm{mL}^{-1}\right)$, demonstrating that our method is highly effective.

Modifications to the DNA extraction protocol of the commercial kit manufacturer were necessary to increase the purity and concentration of the DNA extracted from the açai pulp, as results obtained from previous tests without these modifications demonstrated a large amount of organic contaminants in the extracted DNA, which inhibited PCR (data not shown).

The physicochemical characteristics of açai, along with the pigments present in the fruit, may interfere with DNA extraction and molecular analysis techniques (Yamaguchi et al. 2015; Ferreira et al. 2018; Lucas et al. 2018), and pose a challenge for the detection of $T$. cruzi in açai pulps. The method described here is highly effective due to its advantageous ability to obtain purified DNA, which is not possible using alternative techniques (Godoi et al. 2017). Purified DNA can be obtained using a commercial kit, which contains a purification column with silica gel to which DNA binds. The bound DNA is subsequently washed until a high degree of purity is achieved. This also allows rapid and uniform extraction of DNA samples and eliminates the contaminants and inhibitors which are present in food matrices.

Desjardins and Conklin (2010) used microvolume NanoDrop quantification protocols to estimate the concentration of nucleic acids, and showed that the A260/280 ratio for pure DNA should be between 1.8 and 2.0, and A260/280 ratios outside this range may indicate the presence of proteins, phenols, or other contaminants. They also suggested that the A260/230 ratio for a "pure" nucleic acid should range from 1.8 to 2.2, and lower A260/230 ratios may indicate contamination by carbohydrates, peptides, phenols, and aromatic compounds. Based on this, our DNA samples obtained through the proposed extraction method were of adequate purity, as they fit the parameters suggested by Desjardins and Conklin (2010) for pure DNA samples without contaminants.

The concentration of T. cruzi DNA extracted from açai was lower than that of the positive control DNA extracted from the culture medium. However, the concentration and quality of the extracted T. cruzi DNA were adequate for PCR amplification, suggesting its applicability for commercial açai samples. Ferreira et al. (2018) proposed the use of PCR for $T$.

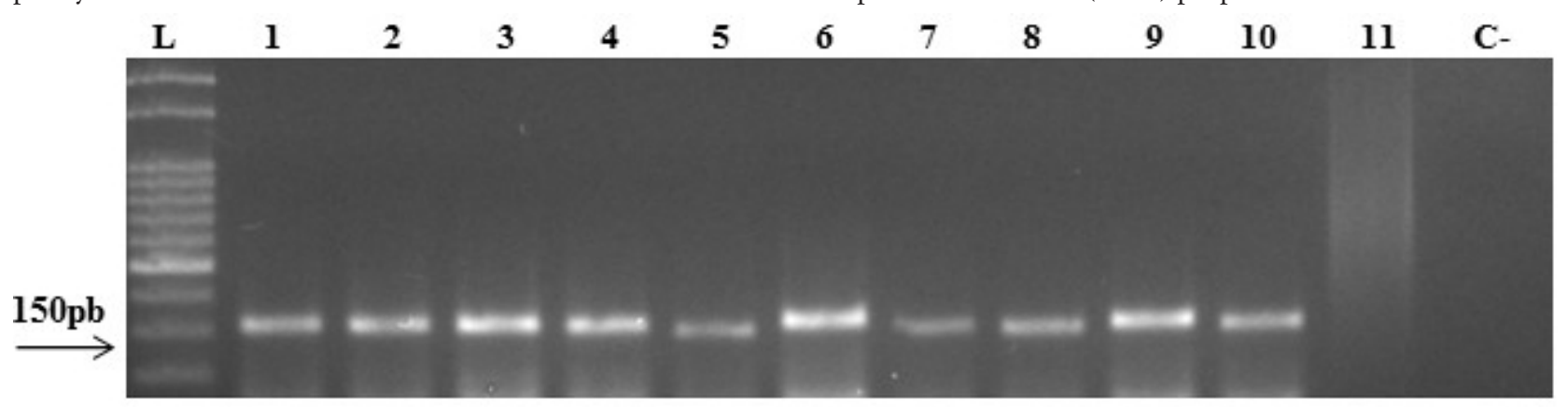

Figure 2. A $2 \%$ agarose gel showing PCR-amplified T. cruzi DNA fragments (149 bp) at different dilutions of T. cruzi inoculated in açai pulp. L: 50 bp marker; lane 1 :

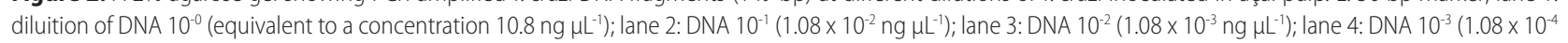

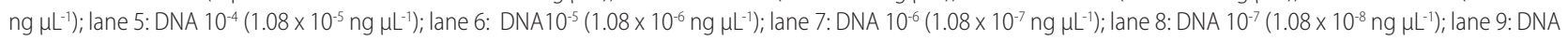

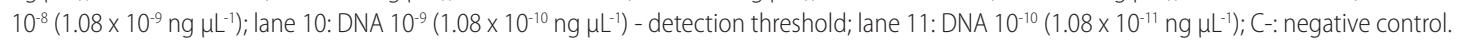




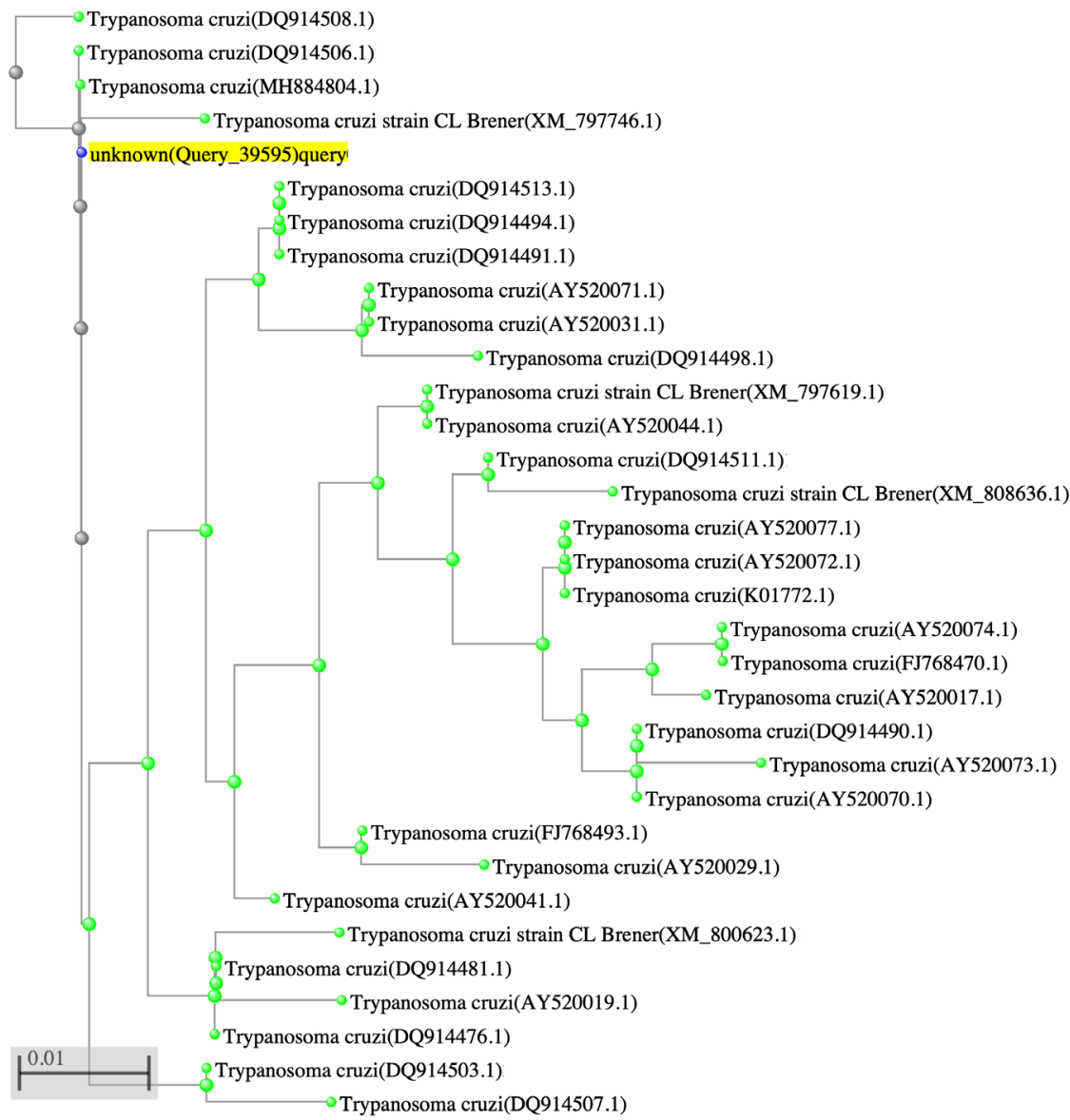

Figure 3. Phylogenetic tree showing the relationship of alignment between sequence pairs presented by the NCBI database query produced from the Blast Tree View ${ }^{\otimes}$ program and containing the name of similar paired species and their identification code. "Unknown (Query_39595)" corresponds to the sample used in this study (Trypanosoma cruzi TcIV). This figure is in color in the electronic version.

cruzi detection in açai samples, tested only with mixtures of DNA, in which the detection limit was $3 \mathrm{pg} \mathrm{LL}^{-1}$. However, our method represented an improvement over theirs because it had a lower detection threshold $\left(1.36 \mathrm{pg} \mu \mathrm{L}^{-1}\right)$.

The sequencing results also confirmed that standard PCR optimized in the present study using the primers described by Ochs et al. (1996) is a robust technique for the detection of $T$. cruzi without nonspecific amplification of other microorganisms. Primers that bind to T. cruzi kinetoplastic minicircle DNA (kDNA) or nuclear satellite DNA (satDNA) might demonstrate variations in the amplified fragments, and may even bind to kDNA or satDNA from other species, such as T. rangeli (Seiringer et al. 2017; Ferreira et al. 2018). However, DNA sequence analysis with other sequences accessed from GenBank did not reveal similarity with genes of other species of the genus Leishmania or other species of Trypanosoma.

\section{CONCLUSIONS}

We conclude that the proposed PCR method is an effective technique for the detection of T. cruzi DNA in açai pulp at concentrations of $1.08 \times 10^{-10} \mathrm{ng} \mathrm{LL}^{-1}$ and above, and could be an important tool for the prevention of Chagas disease caused by the consumption of contaminated pulp of this fruit.

\section{ACKNOWLEDGMENTS}

The authors are grateful to the Coordenaçáo de Aperfeiçoamento de Pessoal de Nivel Superior (CAPES) and Conselho Nacional de Desenvolvimento Científico e Tecnológico (CNPq). We would also like to thank the Protozoology Collection of the Instituto Oswaldo Cruz for providing the positive control and the entire team of the Laboratory of Animal Parasitology of the Veterinary Medicine Institute of Universidade Federal do Pará for their contribution to the contamination phase of this study.

\section{REFERENCES}

Adl, S.M.; Simpson, A.G.; Lane, C.E.; Lucas, J.; Bass, D.; Bowser, S.S. et al. 2013. The revised classification of eukaryotes. Journal of Eukaryotic Microbiology, 59: 429-493.

Alves, M.E.M.; Cadore, G.C.; Oliveira, C.S.; Portella, L.P.; Sangioni, L.A.; Vogel, F.S.F. 2018. Caracterização molecular de Sarcocystis 
spp. em amostras de carne. Pesquisa Veterinária Brasileira, 38: 425-429.

Branquinho, M.R.; Ferreira, R.T.B.; Cardarelli-Leite, P. 2012. Use of real-time PCR to evaluate two DNA extraction methods from food. Food Science and Technology, 32: 112-118.

Brasil. 2019. Doença de Chagas aguda e distribuição espacial dos triatomíneos de importância epidemiológica, Brasil 2012 a 2016. Ministério da Saúde, Boletim Epidemiológico, 50: 2.

Cardoso, G.V.F.; Lima, J.S.; Oliveira, A.C.S.; Silva, J.B; Roos, T.B.; Moraes, C.M. 2020. SYBR green qPCR technique for the detection of Trypanosoma cruzi in açaí pulp. Foodborne Pathogens and Disease, 17: 466-469.

Cássia-Pires, R.; Melo, M.F.; Barbosa, R.D.; Roque, A.L. 2017. Multiplex PCR as a tool for the diagnosis of Leishmania spp. $\mathrm{kDNA}$ and the gapdh housekeeping gene of mammal hosts. PLoS One, 12: e0173922.

Chagas, C. 1909. The discovery of Trypanosoma cruzi and Chagas disease (1908-1909): tropical medicine in Brazil. Brasil Medico, 16: $227-228$.

Costa, H.C.B.; Silva, D.O.; Vieira, L.G.M. 2018. Propriedades físicas da polpa de açaí-berry e estudo cinético de sua degradação térmica de antocianinas. Journal of Food Engineering, 239: 104-113.

Desjardins, P.; Conklin, D. 2010. NanoDrop microvolume quantitation of nucleic acids. Journal of Visualized Experiment, 45: e2565.

Ferreira, R.T.B.; Cabral, M.L.; Martins, R.S.; Araujo, P.F.; Silva Da Silva, B.C.; Branquinho, M.R.; Cardarelli-Leite, P.; Moreira, O.C. 2018. Detection and genotyping of Trypanosoma cruzi from açai products commercialized in Rio de Janeiro and Pará, Brazil. Parasites \& Vectors, 11: e233.

Ferreira, R.T.B.; Melandre, A.M.; Cabral, M.L.; Branquinho, M.R.; Cardarelli-Leite, P. 2016. Extraction of Trypanosoma cruzi DNA from food: a contribution to the elucidation of acute Chagas disease outbreaks. Revista da Sociedade Brasileira de Medicina Tropical, 49: 190-195.

Godoi, P.S.A; Piechnik, C.A.; Oliveira, A.C.; Sfeird, M.Z.; Souza, E.M.; Rogezc, H.; Soccolb, V.T. 2017. qPCR for the detection of foodborne Trypanosoma cruzi. Parasitology International, 66: 563-566.

Lewis, M.D.; Francisco, A.F.; Jayawardhana, S.; Langston, H.; Taylor, M.C.; Kelly, J.M. 2018. Imaging the development of chronic Chagas disease after oral transmission. Scientific Reports, 8: e11292.

Lucas, B.F.; Zambiazi, R.C.; Costa, J.A.V. 2018. Biocompounds and physical properties of açai pulp dried by different methods. Food Science and Technology, 8: 335-340.

Mattos, E.C.; Meira-Strejevitch, C.S.; Marciano, M.A.M.; Faccini, C.C.; Lourenço, A.M.; Pereira-Chioccola, V.L. 2017. Molecular detection of Trypanosoma cruzi in açai pulp and sugarcane juice. Acta Tropica, 176: 311-315.
Nathan-Larrier, L. 1921. Infections à Trypanosomes at voies de penetrations des vírus. Bulletin de la Société de Pathologie Exotique, 14: 537-542.

Ochs, D.E.; Moser, D.R.; Smith, J.H.; Kirchhoff, L.V. 1996. Postmortem diagnosis of autochthonous acute chagasic myocarditis by polymerase chain reaction amplification of a species-specific DNA sequence of Trypanosoma cruzi. The American Journal of Tropical Medicine and Hygiene, 5: 526-529.

Oliveira, A.C.S.; Rosa, M.C.; Borchardt, J.L.; Menegon, Y.A.; Fernandes, M.M.A.; Cardoso, G.V.F.; et al. 2018. Validating the Efficiency of a Simplex PCR and Quantitative SYBR Green qPCR for the Identification of Salmonella spp. DNA. Journal of Food: Microbiology, Safety and Hygiene, 3: e1000130.

Santos, A.; Cremades, R.; Rodriguez, J.C.; García-Pachón, E.; Ruiz, M.; Roy, G. 2009. Comparison of methods of DNA extraction for real-time PCR in a model of pleural tuberculosis. Acta Pathologica, Microbiologica et Immunologica Scandinavica, 118: 60-65.

Seiringer, P.; Pritsch, M.; Flores-Chaves, M.; Marchisio, E.; Helfrich, K.; Mengele, C.; et al. 2017. Comparison of four PCR methods for efficient detection of Trypanosoma cruzi in routine diagnostics. Diagnostic Microbiology and Infectious Disease, 88: 225-232.

Silveira, A.P.S.D.; Vieira, V.B.D.; Batalini, L.S.; Carmo, S.B.D.; Friozi, E.; Arruda, E.J.; Lima Junior, M.S.D.C.; Neitzke-Abreu, H.C. 2018. PCR sensitivity of peripheral blood of dogs coinfected with Leishmania spp. and Ehrlichia spp. in endemic area of Brazil. Revista da Sociedade Brasileira de Medicina Tropical, 51: 843-847.

Shikanai-Yasuda, M.A.; Carvalho, N.B. 2018. Oral transmission of Chagas disease. Emerging Infections, 54: 845-842.

WHO. 2017. Integrating neglected tropical diseases into global health and development: fourth WHO report on neglected tropical diseases. World Health Organization, Geneva. (https:// www.who.int/publications/i/item/9789241565448).

Xavier, S.C.C.; Roque, A.L.R.; Bilac, D.; Araùjo, V.A.L.; Neto, S.F.C.; Lorosa, S.E.; Silva, L.F.C.F.; Jansen, A.M. 2014. Distantiae transmission of Trypanosoma cruzi: a new epidemiological feature of acute Chagas disease in Brazil. PloS Neglected Tropical Diseases, 8: e2878.

Yamaguchi, K.K.L.; Pereira, L.F.R.; Lamarão, C.V.; Lima, E.S.; Veiga-Junior, V.F. 2015. Amazon acai: chemistry and biological activities: A review. Food Chemistry, 179: 137-151.

Yoshida, N. 2008. Molecular mechanisms of infection by oral route. Memórias do Instituto Oswaldo Cruz, 104: 101-107.

\section{RECEIVED: 04/09/2019 \\ ACCEPTED: 08/12/2020 \\ ASSOCIATE EDITOR: Izeni P. Farias}

This is an Open Access article distributed under the terms of the Creative Commons Attribution License, which permits unrestricted use, distribution, and reproduction in any medium, provided the original work is properly cited. 